\title{
BUDOWANIE STRATEGII ZARZĄDZANIA BHP W PRZEDSIĘBIORSTWIE
}

\begin{abstract}
Streszczenie: Każde przedsiębiorstwo stara się budować jak najbardziej efektywne działanie. Ważnym, aczkolwiek często niedostrzeganym elementem budowania strategii jest zarządzanie bezpieczeństwem i higieną pracy. Budowanie strategii zarządzania BHP w przedsiębiorstwie obywa się przy współudziale służby BHP, która określa stan bezpieczeństwa w środowisku pracy oraz wskazuje możliwości jego poprawy. Współdziałanie z pracodawcą oraz kierownictwem pozwala na wykształcenie odpowiednich mechanizmów, które mają na celu poprawę bezpieczeństwa środowiska pracy. Przedmiotem opracowania jest budowa strategii zarządzania BHP w wybranym przedsiębiorstwie.
\end{abstract}

Słowa kluczowe: zarządzanie BHP, służba BHP, zarządzanie przedsiębiorstwem,

\section{Wprowadzenie}

Wszelkie działania, jakie podejmuje przedsiębiorca nakierowane są na realizację celów. W zależności od ich koncentracji, można określić cele związane z rozwojem, ewentualnie cele nakierowane na zysk. Niemniej jednak każda decyzja podejmowana przez przedsiębiorcę determinowana jest przez procesy zarządzania. Literatura przedmiotu wyróżnia wiele definicji zarządzania, w zależności od danego podejścia.

Jednym z istotnych elementów zarządzania przedsiębiorstwem są kwestie związane $\mathrm{z}$ bezpieczeństwem i higieną pracy. Obowiązki, jakie spoczywają na pracodawcy determinowane są przez akty normatywne oraz normy, dlatego też w zarządzaniu przedsiębiorstwem nie mogą one zostać pominięte. Włączenie aspektów bezpieczeństwa w proces zarządzania przedsiębiorstwem jest bardzo istotne, z punktu widzenia efektywności np.: produkcji, ponieważ niewłaściwe warunki pracy mogą spowodować zdarzenia wypadkowe, które będą skutkować stratami materialnymi i niematerialnymi. Realizacja poszczególnych elementów zarządzania (np.: zarządzania zasobami ludzkimi): planowania, organizowania, motywowania i kontrolowania nie może się odbywać bez zwrócenia uwagi na elementy bezpieczeństwa i higieny pracy (BHP). Przedsiębiorca powinien mieć wdrożone mechanizmy kształtujące bezpieczne środowisko pracy [1]. Przedmiotem opracowania jest budowanie strategii zarządzania BHP w przedsiębiorstwie. Problematyka strategii

\footnotetext{
${ }^{1}$ Dr, Politechnika Rzeszowska, awozny@ prz.edu.pl

${ }^{2}$ Mgr, Podkarpackie Centrum Usług Dydaktycznych, mdobosz@pcud.edu.pl

${ }^{3}$ Mgr, Podkarpackie Centrum Usług Dydaktycznych, psaja@pcud.edu.pl
} 
zarządzania została przedstawiona na przykładzie przedsiębiorstwa usługowohandlowego posiadającego hale magazynowe i posiadająca 19 oddziałów w Polsce. Przedsiębiorstwo zatrudnia około 700 osób. Skoordynowanie działań związanych z zarządzaniem BHP wymagało od służby BHP określenia strategii.

\section{Zarządzanie BHP}

Efektywne zarządzanie przedsiębiorstwem nie może obejść się bez właściwych mechanizmów kształtujących bezpieczne i higieniczne środowisko pracy. Istotą oraz gwarancją kultury bezpieczeństwa $\mathrm{w}$ przedsiębiorstwie jest sprawnie funkcjonujący system zarządzania BHP. Należy zwrócić uwagę na fakt, że zrządzanie BHP stanowi element ogólnego zarządzania przedsiębiorstwem, dlatego też w jego planowaniu i organizacji ważny jest aktywny współudział pracodawcy, kadry zarządzającej i pracowników. Głównymi elementami, których dotyczy zarządzanie BHP związane jest $\mathrm{z}$ dostosowaniem środowiska pracy do spełnienia minimalnych wymagań określonych w aktach normatywnych. Jednakże efektywne zarządzanie BHP to takie, które nie tylko wywiązuje się z wymagań określonych przepisami prawa pracy, ale planuje, organizuje, motywuje i kontroluje wszelkie procesy kształtujące się wewnątrz i na zewnątrz przedsiębiorstwa, które dotyczą kwestii bezpieczeństwa. Można zadać pytanie, dlaczego zarządzanie BHP jest tak ważne dla przedsiębiorstwa? Poza argumentami ekonomicznymi, gdzie wypadki lub zdarzenia wypadkowe mogą powodować przestoje i straty materialne, należy podkreślić, iż bezpieczne warunki pracy wymusza na polskich przedsiębiorstwach Dyrektywa Ramowa Unii Europejskiej nr 89/391/EWG [2].

Istotnym elementem zarządzania BHP jest ocena ryzyka zawodowego na poszczególnych stanowiskach pracy. Ryzyko zawodowe jest to prawdopodobieństwo wystąpienia zdarzeń niepożądanych $\mathrm{w}$ miejscu pracy lub związanych z czynnościami pracy, które mogą spowodować uraz lub śmierć pracownika. Zgodnie z $§ 39$ ust. 1 Rozporządzenia Ministra Pracy i Polityki Socjalnej z 26 września 1997 r. w sprawie ogólnych przepisów bezpieczeństwa i higieny pracy (Dz.U. Nr 129, poz. 844 ze zm.) pracodawca jest obowiązany oceniać i dokumentować ryzyko zawodowe, występujące przy określonych pracach, oraz stosować niezbędne środki profilaktyczne zmniejszające ryzyko [3]. Kodeks pracy w art. 226 wskazuje, że pracodawca zobowiązany jest poinformować pracowników o ryzyku zawodowym oraz przedsięwziąć środki zmniejszające ryzyko zawodowe [4].

Kształtowanie zarządzania BHP rozpoczyna się w zasadzie od właściwej oceny ryzyka zawodowego. Poprzez poznanie stanowisk pracy, maszyn i urządzeń możliwe jest zidentyfikowanie zagrożeń, oraz następnie oszacowanie ryzyka ich wystąpienia. $\mathrm{Na}$ tej podstawie możliwe jest budowanie strategii zarządzania bezpieczeństwem, 
gdyż funkcjonująca służba BHP w przedsiębiorstwie ma obraz zagrożeń, które mogą spowodować stratę materialną oraz stratę w zasobach ludzkich (np.: wypadki w pracy, zwolnienia chorobowe, choroby zawodowe itp.) [5].

Posiadanie przez przedsiębiorstwo przemyślanej strategii zarządzania BHP pozwala na zwiększenie zaangażowania pracowników w szerzenie kultury bezpieczeństwa $\mathrm{w}$ zakładzie pracy. Wpływa to również na zwiększenie jakości i wydajności pracy w zakładzie. Dbanie o właściwe warunki pracy poprzez np.: regularne przeglądy maszyn i urządzeń, dbanie o środki ochrony indywidualnej, respektowanie norm czasu pracy itp., w dłuższej perspektywie przynosi wymierne korzyści, gdyż zwiększa się satysfakcja pracowników z wykonywanej pracy - co ma istotne znaczenie dla wydajności i jakości pracy. Warto podkreślić, że sprawnie funkcjonujący system zarządzania BHP nie ogranicza ilości wyprodukowanych dóbr, czy zrealizowanych usług.

Bezpieczne i higieniczne warunki pracy zapewniają mniejszą rotację pracowników, przez co pracodawca ponosi mniejsze koszty związane $\mathrm{z}$ badaniami lekarskimi, szkoleniami, czy wyposażeniem pracowników w środki ochrony indywidualnej. Warto zwrócić uwagę, że nowy pracownik jest bardziej narażony na potencjalne zagrożenia $\mathrm{w}$ zakładzie pracy oraz czynności wykonuje wolniej, niż pracownicy $z$ doświadczeniem. Dlatego też $w$ interesie pracodawcy jest to, aby poza motywatorami płacowymi (pensja, premie, dodatki funkcyjne, zakładowy fundusz świadczeń socjalnych itp.) stosowano motywatory pozapłacowe (pochwały za bezpieczną pracę, dodatkowe szkolenia, lepsze środki ochrony indywidualnej itp.).

Kolejnym argumentem wskazującym, iż efektywne zarzadzanie BHP przynosi korzyść dla pracodawcy jest to, iż zwiększona liczba zdarzeń wypadkowych i chorób zawodowych w przedsiębiorstwie może generować wzrost kosztów związanych ze składkami chorobowymi, czy wypadkowymi. W przypadku średnich i dużych przedsiębiorstw może to być znacząca kwota, gdyż w przypadku poniesienia składki będzie ona dotyczyła wszystkich pracowników.

$\mathrm{W}$ analizowanym przedsiębiorstwie funkcjonowało zarządzanie BHP wyłącznie w teorii. Przed zmianą, służba BHP istniała teoretycznie, czyli ograniczała się wyłącznie do minimalnych wymagań stawianych przez akty prawne. Ograniczało się to do:

- Szkoleń wstępnych i okresowych (jednakże znaczna część pracowników nie posiadała szkoleń wstępnych i okresowych),

- Oceny ryzyka zawodowego (nieaktualizowane od 4 lat, pomimo zmiany stanowisk pracy i zakresu czynności na niektórych stanowiskach),

Brak właściwego zarządzania BHP powodował, iż w roku 2017 odnotowano 34 wypadki w pracy. Warto zwrócić uwagę, że poprzednia służba BHP nie prowadził rejestru zdarzeń potencjalnie wypadkowych przez co trudno jest określić skalę ryzyka wystąpienia wypadku w pracy. 
Zmiana służby BHP, oraz wsparcie firmy zewnętrznej świadczącej usługi BHP determinowała szereg procesów w zarządzaniu BHP. Wnioski z zaistniałych wypadków przy pracy, przeprowadzona analiza dokumentacji oraz rozmowy z pracownikami sprawiły, że podjęto decyzję o budowie nowej strategii zarządzania BHP w przedsiębiorstwie.

\section{Budowanie strategii BHP}

Strategiczne podejście do zarządzania BHP związane jest nie tylko $\mathrm{z}$ dostosowaniem przedsiębiorstwa do wymagań stawianych przez akty normatywne i normy. Rozumieć przez to należy określoną filozofię zarządzania, na podstawie której prowadzone są działania nakierowane na osiągnięcie dokładnie przemyślanych celów opartych na bezpieczeństwie. Spójność tych celów musi odzwierciedlać ogólne cele przedsiębiorstwa. Zbiór uporządkowanych działań podejmowanych w zakładzie pracy jest wypadkową oddziaływań na bezpieczeństwo i higienę pracy.

Realizacja określonych celów odbywa się poprzez wiele programów operacyjnych, które są wzajemnie zintegrowane. Przyjęta przez dane przedsiębiorstwo metodologia strategii BHP odzwierciedla wszystkie dotychczasowe działania oraz wskazuje nowe kierunki, w jakie będzie podążać. W głównej mierze budowanie strategii BHP opiera się na:

- Strukturze organizacyjnej,

- Możliwościach służby BHP (jej kwalifikacjach, doświadczeniach, kompetencji osób wchodzących w jej skład),

- Dostępnych zasobach finansowych,

- Dostępnych zasobach materialnych,

- Inwestycjach w zasoby ludzkie,

- Systemie wsparcia kadry zarządzającej itp.[6].

\subsection{Proces budowy strategii}

Najważniejszym elementem budowy strategii zarządzania BHP jest zaangażowanie wszystkich zasobów ludzkich. Świadomość najwyższego kierownictwa co do zarządzania BHP dotyczy zrozumienia, iż bezpieczne środowisko pracy jest nie tylko wartością konieczną determinowaną przez prawo, ale stanowi ważny element rozwoju przedsiębiorstwa i chęci osiągnięcia większych zysków. Kierownictwo wraz ze służbą BHP angażuje pozostałych pracowników w strukturze organizacyjnej. Podejście strategiczne związane jest $\mathrm{z}$ uczestnictwem zasobów ludzkich w procesach, które mają na celu kształtowanie kultury BHP. Pracownikom 
niższego szczebla należy uświadomić, że wdrożona strategia przyniesie wymierne korzyści w postaci bezpieczniejszych warunków pracy.

Strategiczne podejście do zarządzania BHP determinuje wybór metodologii procesowej. Zastosowanie metod organizacyjnych opartych np.: na Lean management pozwala nie tylko uporządkować stanowiska pracy, ale wykształcić zachowania i nawyki ciągłego doskonalenia warunków bezpieczeństwa w środowisku pracy. Ciągłe doskonalenie dotyczy nie tylko zwiększenia nakładów finansowych związanych np.: z modernizacją maszyn i urządzeń, ale również ze stałym szkoleniem pracowników i budowaniem odpowiedzialności za bezpieczeństwo. Doskonalenie strategicznego zarządzania BHP związane jest z podejmowaniem inwestycji w zasoby ludzkie. Kapitał intelektualny, jaki posiadają pracownicy jest jednym z głównych źródeł przewagi konkurencyjnej, $\mathrm{w}$ tym również związanej $\mathrm{z}$ bezpieczeństwem. Pracownicy świadomi i odpowiedzialni za bezpieczeństwo w środowisku pracy są pożądani przez pracodawców, gdyż nie generują zbędnych kosztów lub strat wynikających z niewłaściwego zachowania, czy zwiększoną ilością dni chorobowych. Odpowiedzialność za środowisko pracy spoczywa na całym zespole pracowników, gdyż każda jednostka jest odpowiedzialna za wypracowanie zysku w przedsiębiorstwie.

Strategiczne zarządzanie BHP polega również na konstruowaniu odpowiednich strumieni oddziaływań na poprawę bezpieczeństwa w środowisku pracy. Odpowiednie motywowanie pracowników pozwala nie tylko szybciej wychwycić nieprawidłowości, ale również może doprowadzić do zwiększenia uczestnictwa pracowników w kształtowanie kultury BHP. Opracowanie odpowiedniej strategii związane jest z takimi uwarunkowaniami przedsiębiorstwa, które pozwalają na wykorzystanie jego silnych stron oraz niwelowania słabych. Analiza przedsiębiorstwa np.: poprzez analizę SWOT pozwala wykazać, które poszczególne elementy funkcjonowania przedsiębiorstwa wymagają natychmiastowej reakcji. Z doświadczenia autora opracowania wynika, że najczęstsza sytuacją, która natychmiast wymaga reakcji są zasoby ludzkie, które często są niewyedukowane, jeśli chodzi o kwestie bezpieczeństwa. Jakość prowadzonych szkoleń BHP oraz kontakt służby BHP $\mathrm{z}$ pracownikami jest na niskim poziomie. Jest to nieprawidłowe działanie przedsiębiorcy, który powinien zachęcać pracowników do współpracy ze służbą BHP [7].

Monitorowanie zachowań niepożądanych $\mathrm{w}$ środowisku pracy umożliwia zastosowanie działań korygujących i zapobiegawczych. Podejście służby BHP do strategicznego zarządzania wymaga dużego zaangażowania. Rysunek 1 przedstawia schemat procesu budowy strategii zarządzania BHP. 


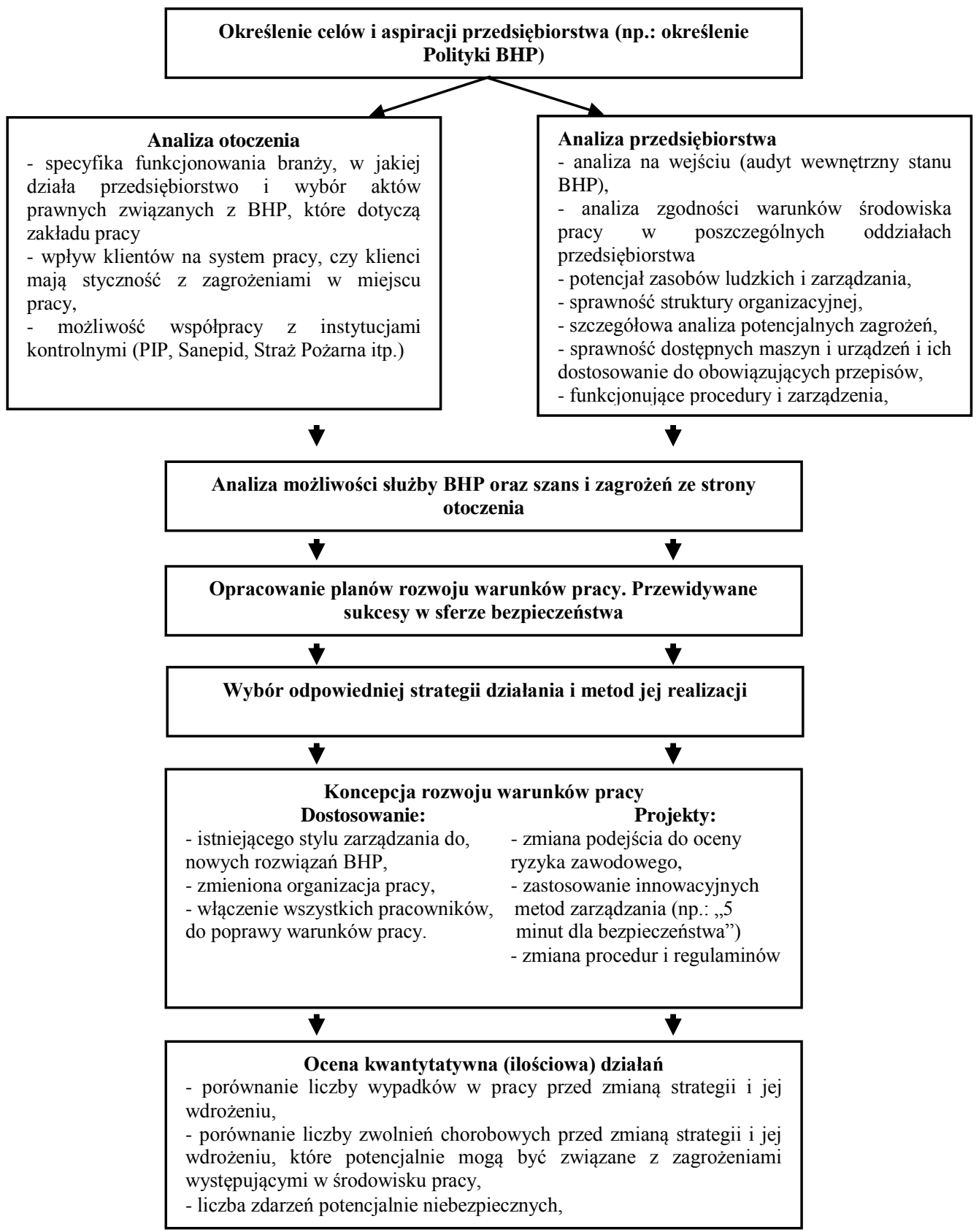

Rys. 1. Proces budowy strategii zarzqdzania BHP w analizowanym przedsiębiorstwie Źródto: Opracowanie wtasne na podstawie [8] 


\subsection{Metody zastosowane do realizacji strategii}

Działania przeprowadzone przez służbę BHP spowodowały budowę nowej strategii zarządzania BHP w przedsiębiorstwie. W przypadku analizowanej firmy było to konieczne, gdyż duża liczba pracowników i oddziałów sprawiała, że bezpieczeństwo środowiska pracy jest dość mocno zróżnicowane. Podczas szczegółowej analizy na wejściu wskazano, iż w oddziałach, które były najrzadziej audytowane przez poprzednią służbę BHP było najwięcej zdarzeń wypadkowych i najgorsze warunki pracy. Budowanie nowej strategii opartej na optymalizacji warunków środowiska pracy $\mathrm{w}$ każdym oddziale jest kluczem do rozwoju przedsiębiorstwa. Dlatego też służba BHP zastosowała szereg metod, które mają ułatwić nie tylko monitorowanie środowiska pracy, ale i zaangażowanie wszystkich pracowników w kwestie BHP.

Pierwszą z metod zastosowanych w budowaniu nowej strategii jest jakościowe podejście do szacowania ryzyka zawodowego. Zagrożenia, jakie wynikają ze specyfiki funkcjonowania przedsiębiorstwa zostały uzupełnione o zagrożenia, jakie występują w poszczególnych oddziałach przedsiębiorstwa. Przykładem słuszności takiego działania jest zwrócenie uwagi w jednym oddziale na wiek pracowników. Z racji starszego wieku pracowników w tym oddziale (ale i dużego doświadczenia) zastosowano inną instrukcję ręcznych prac transportowych oraz zmniejszono normę przenoszenia towarów (do $20 \mathrm{~kg}$ przy pracy stałej [rozporządzenie dopuszcza do $30 \mathrm{~kg}$ ]) oraz zmniejszono normę przenoszenia towarów ręcznymi wózkami paletowymi (do $350 \mathrm{~kg}$ [rozporządzenie dopuszcza do $450 \mathrm{~kg}$ ]). Takie działanie sprawiło, iż zmniejszyło się ryzyko przeciążenia układu mięśniowo-szkieletowego, przez co odnotowano wyraźny spadek zwolnień chorobowych związanych $\mathrm{z}$ tą dolegliwością. Indywidualne podejście do szacowania ryzyka zawodowego pozwala na dostosowanie warunków pracy do specyfiki oddziału, jego zasobów ludzkich, czy infrastruktury.

Kolejną z metod, które zostały ujęte w nowej strategii zarządzania to zmiana organizacji szkoleń BHP. O ile nadal spełnia się wymagania określone w Rozporządzeniu Ministra Gospodarki i Pracy z dnia 27 lipca 2004 r. w sprawie szkolenia w dziedzinie bezpieczeństwa i higieny pracy (Dz.U. 2004 nr 180 poz. 1860), to dodatkowo zastosowano metodę „5 minut dla bezpieczeństwa”, która pierwotnie została stworzona dla Katowickiego Holdingu Węglowego. Polega ona na cyklicznych 5 minutowych szkoleniach (metodą aktywizującą) wszystkich pracowników. Podczas tych szkoleń zwraca się uwagę przede wszystkim na problemy, jakie dostrzegają sami pracownicy luk kadra zarządzająca [9]. Umożliwienie pracownikom zaproponowanie rozwiązań tych problemów zwiększa prawdopodobieństwo ich realizacji. Szczegółowy opis i zastosowanie tej metody znajduje się w oddzielnym opracowaniu w tej monografii (A. Woźny, P. Saja, M. Dobosz, Wplyw metody ,,5 minut dla bezpieczeństwa" na kulturę bhp w przedsiębiorstwie). 
$\mathrm{Z}$ racji dużego rozproszenia oddziałów na terenie Polski oraz dużego wskaźnika wypadkowości, służba BHP zaproponowała wyznaczenie w każdym oddziale społecznego inspektora pracy, który ma za zadanie monitorować zdarzenia potencjalnie niebezpieczne i raportować je służbie BHP znajdującej się w głównym oddziale. Działanie to znacząco ułatwia monitorowanie stanu bezpieczeństwa w poszczególnych oddziałach. Rolą społecznego inspektora pracy jest również wstępne gromadzenie dokumentacji niezbędnej do sporządzenia protokołu powypadkowego oraz karty wypadkowej (w przypadku wypadku w drodze do lub z pracy).

Działania prowadzone przez służbę BHP są w ciągłej realizacji, przez co zastosowanie innych metod wymaga analizy skuteczności. Z racji dużej liczby pracowników i oddziałów, wdrożenie nowej strategii musi być rozłożone w czasie. Jednakże warto podkreślić, iż już pierwsze miesiące wdrożenia nowej strategii przyniosły wymierne korzyści. W I kwartale 2018 r. odnotowano zaledwie 3 wypadki w pracy podczas, gdy w analogicznym okresie 2017 r., tych wypadków było już 7 . Jest to pozytywny prognostyk przed głęboką analizą stanu BHP po roku czasu od wdrożenia nowej strategii bezpieczeństwa.

\section{Podsumowanie}

Działania podejmowane przez służbę BHP mają na celu poprawę warunków bezpieczeństwa i higieny pracy. W przypadku dużych przedsiębiorstw, które posiadają wiele oddziałów jest to niezwykle trudne. Budowa odpowiedniej strategii zarządzania BHP pozwala nie tylko określić stan faktyczny bezpieczeństwa w poszczególnych oddziałach, ale również nakreślić ogólne ramy bezpieczeństwa dla wszystkich oddziałów. Budowa strategii i jej wdrożenie jest procesem długotrwałym, ale pierwszych efektów można się spodziewać już w pierwszych miesiącach po zmianach. Ukazuje to przykład przedsiębiorstwa opisanego w opracowaniu, gdzie stosunkowo szybko zmniejszył się wskaźnik wypadkowości. Ciągłe doskonalenie strategii poprzez stosowanie nowych metod nie tylko pozwoli na stworzenie bezpiecznych i higienicznych warunków pracy, ale również zwiększy jakość i wydajność pracy pracowników.

Istotne jest, aby strategia zarządzania BHP była przemyślana i możliwa do zrealizowania. Należy określić zasoby, które można wykorzystać przy budowaniu strategii, aby nie okazało się, że pomimo najlepiej opracowanej strategii brak jest odpowiednich zasobów ludzkich i finansowych do jej realizacji. Nie bez znaczenia jest również doświadczenie i kwalifikacje służby BHP. 


\title{
Bibliografia
}

[1] Woźny A., Dobosz M., Podstawowa dokumentacja służb BHP, Wyd. Indygo, Rzeszów, 2014.

[2] Woźny A., Pacana A., Dobosz M., Saja P., Bezpieczna praca determinantem jakości $i$ wydajności organizacji, Humanities and Social Sciences vol.20, Wyd. Politechnika Rzeszowska, Rzeszów, 2015.

[3] Rozporządzenia Ministra Pracy i Polityki Socjalnej z 26 września 1997 r. w sprawie ogólnych przepisów bezpieczeństwa i higieny pracy (Dz.U. Nr 129, poz. 844 ze zm.).

[4] Ustawa z dnia 26.06.1974 r. Kodeks pracy (Dz. U. z 2018 r. poz. 917 z późn. zm.)

[5] Woźny A., Pacana A., Ocena ryzyka zawodowego. Teoria i przykłady, Wyd. Politechnika Rzeszowska, Rzeszów, 2014.

[6] Pacana A., Wdrażanie, auditowanie $i$ doskonalenie systemów zarządzania bezpieczeństwem $i$ higiena pracy zgodnych z PN-N-18001, Wyd. Politechnika Rzeszowska, Rzeszów, 2013.

[7] Gajdzik B., Podejście strategiczne do doskonalenia systemu zarzadzania bezpieczeństwem $i$ higiena pracy $w$ przedsiębiorstwie hutniczym, Zeszyty naukowe wyższej szkoły zarządzania ochrona pracy w Katowicach vol. 1(6)/2010

[8] Penc J., Projektowanie strategii przedsiębiorstwa, "Organizacja i Kierowanie", nr 2 (72), 1993.

[9] CIOP, 5 Minut dla bezpieczeństwa [online: 10.06 .2018 r.] https://www.ciop.pl/CIOPPortalWAR/appmanager/ciop/pl?_nfpb=true\&_pageLabel= P27800138621413525576340\&html_tresc_root_id=16499\&html_tresc_id=16610\&ht ml_klucz=16499\&html_klucz_spis=

\section{BUILDING A HEALTH AND SAFETY MANAGEMENT STRATEGY IN THE ENTERPRISE}

\begin{abstract}
Every enterprise tries to build the most effective company strategy. An important, though often overlooked element of strategy building is occupational health and safety management. Building an occupational health and safety management strategy in an enterprise is done in cooperation with the health and safety service, which determines the state of safety in the work environment and indicates the possibilities of its improvement. Cooperation with the employer and management allows for the development of appropriate mechanisms that aim to improve the safety of the work environment. The subject of the study is the construction of a health and safety management strategy in a selected company.
\end{abstract}

Key words: health and safety management, health and safety service, business management, 